\title{
150 ANOS DEPOIS: narrativas históricas de jovens estudantes brasileiros/as sobre a Guerra do Paraguai/Guerra Guasu a partir das aulas de História
}

Ana Paula Squinelo*

RESUMO: A Guerra do Paraguai (1864-1870) é considerada uma "história difícil" e traumática para a América Latina, desde seu término constituiu-se em um dos conteúdos escolares sujeitos a inúmeras revisões e manipulações históricas. A partir de pressupostos da Educação Histórica, buscou-se responder à pergunta: "O que os/as estudantes compreendem sobre o conteúdo Guerra do Paraguai a partir das narrativas didáticas e das aulas de história?". Para tal formulou-se um Instrumento de Pesquisa pertinente à temática que foi aplicado junto a 151 estudantes de cinco escolas públicas do estado de Mato Grosso do Sul (Brasil/MS). Nessa análise apresentamos os resultados dessa investigação.

PALAVRAS-CHAVE: Guerra do Paraguai/Guerra Guasu; Livro didático de história; Aulas de História; Narrativas de estudantes.

\section{0 years later: Historical narratives of young brazilian students on the Paraguayan War/Guasu War from history classes}

ABSTRACT: The Paraguayan War (1864-1870) is considered a "difficult history" and traumatic for Latin America, since its completion it has been one of the school contents subject to numerous revisions and historical manipulations. Based on the assumptions of Historical Education (BARCA 2001), we sought to answer the question: "What do students understand about the content of the War of Paraguay from didactic narratives and history classes?". For this purpose, a Research Instrument related to the theme was formulated and applied to 151 students from five public schools of Mato Grosso do Sul (Brazil/MS). In this analysis, we present the results of this investigation.

KEYWORDS: War of Paraguay/War Guasu; History textbook; History Classes; Student narratives.

\section{0 años después: narrativas históricas de jóvenes estudiantes brasileños sobre la guerra del Paraguay / Guerra Guasu de las clases de historia}

RESUMEN: La Guerra del Paraguay (1864-1870) es considerada una "historia difícil y traumática" para América Latina, ya que desde su final ha sido uno de los contenidos escolares sujetos a numerosas revisiones y manipulaciones históricas. Partiendo de los supuestos de la Educación Histórica, buscamos dar respuesta a la pregunta: “¿Qué entienden los estudiantes sobre el contenido de la Guerra de Paraguay a partir de narrativas didácticas y clases de historia?”. Para ello, se formuló un Instrumento de Investigación relevante al tema, que se aplicó a 151 estudiantes de cinco escuelas públicas del estado de Mato Grosso do Sul (Brasil/MS). En este análisis, presentamos los resultados de esta investigación.

PALAVRAS CLAVE: Guerra del Paraguay / Guerra Guasu; Libro texto de Historia; Clases de Historia; Narrativas de estudiantes.

\footnotetext{
*Pós-Doutora pela Universidade do Minho (Braga/Portugal). Atualmente é Professora Associada do curso de História da Universidade Federal de Mato Grosso do Sul - Campus de Aquidauana. Contato: Rua Monte Azul, 1060, Vila Marli, CEP 79.117-020, Campo Grande-MS, Brasil. E-mail: apsquinelo@yahoo.com.br. ORCID: https://orcid.org/0000-0003-4490-5111
} 
Sobre a Guerra do Paraguai:

Eu não sei muita coisa, sei pouca.

Só guardo as coisas que me interessam e que eu sei que vai me ajudar.

(AJSVR, 16 anos, 2017)

No que tange à historiografia didática ${ }^{1}$ pertinente à Guerra do Paraguai, podemos afirmar com certa margem de segurança que temos, hoje, uma publicação considerável e significativa produzida por investigadores/as platinos. Oficialmente denominada no Brasil de Guerra do Paraguai, o conflito ocorrido entre os anos de 1864-1870 e que envolveu Brasil, Paraguai, Argentina e Uruguai, no Paraguai é conhecido por Guerra Guasu, Guerra Grande, Guerra da Tríplice Aliança e, ainda, Guerra da Tríplice Aliança contra o Paraguai. Longe de ser consenso, a própria terminologia por si poderia se configurar como objeto de investigação, tendo em vista que se imbrica em contextos políticos, econômicos, culturais, sociais e ideológicos de cada país que esteve involucrado nessa contenda.

De seu término e passados os 150 anos do conflito, foi alvo de inúmeras e diferenciadas (re) interpretações, seja pela produção das escritas de si (memórias, cartas, reminiscências, diários), pelas obras históricas e historiográficas sobre o tema, seja pela produção de uma historiografia didática que se debruçou sobre este assunto. Em seguida ao seu término - ocorrido em 01 de março de 1870 - muitos memorialistas, militares ou não, elaboraram suas interpretações sobre aquele passado histórico recente. Tais interpretações influenciaram em grande medida a produção didática sobre o tema. No Brasil, por exemplo, os manuais didáticos de Joaquim Manoel de Macedo (1905) e de Rocha Pombo (1917; 1925; 1960) divulgaram amplamente imagens sobre o conflito guarani, aquele que é considerado o maior conflito da América Latina; no Paraguai, o Compêndio de Teran e Gamba (1920) exerceu enorme influência no que se refere às ideias a serem veiculadas sobre o Paraguai no pós-Guerra. O fim do século XIX e o "longo século XX” foram marcados, portanto, por duas questões, a saber: a produção de manuais didáticos que veicularam determinada ideia sobre o Paraguai, tanto no Brasil como no Paraguai e, ao mesmo tempo, uma produção que se dedicou e se dedica a compreender essas narrativas didáticas sobre o conflito.

Nessa seara, investigações com várias abordagens e olhares foram e continuam sendo realizadas, das quais citamos as que consideramos pertinentes: em relação aos estudos sobre manuais didáticos de história na perspectiva da história comparada, no caso Brasil e Paraguai, vale ressaltar as análises de Squinelo (2002) e Salles (2016; 2017); no que se refere às pesquisas sobre manuais didáticos de história brasileiros e à Guerra do Paraguai/Guerra 
Guasu sob diferenciadas perspectivas no âmbito do Ensino Fundamental II, citamos como exemplo os estudos de Squinelo $(2011 ; 2014 ; 2015)$ e, no âmbito do Ensino Médio, vale destacar as reflexões de Araújo (2016; 2020) e Dockhorn (2020). Sales, 2020, refletiu ainda sobre a questão da formação de professores/as e o conteúdo escolar Guerra do Paraguai, e sobre a questão dos livros paradidáticos e a Guerra Guasu, Squinelo (2019; 2020) apresentou um balanço significativo do tema. Pontuamos, também, os estudos relativos aos manuais militares brasileiros utilizados para a formação de alunos (futuros militares), desenvolvidos por Squinelo (2002). Sobre a questão dos protagonistas subalternos no contex to da Guerra vale a pena conferir a pesquisa de Dockhorn (2020) e, por fim, sobre investigações que produziram materiais objetivando subsidiar o trabalho do/a professor/a em contexto do ensino da educação básica, citamos: Kmiecik (2016), Moreira (2018) Dockhorn (2020) e Squinelo (2020). Em diálogo com investigadores/as do Prata e ainda no que se refere à historiografia didática concernente à Guerra do Paraguai/Guerra Guasu, cabe menção aos seguintes estudos: do uruguaio Sansón Corbo (2011), do argentino Telesca (2015) e, por fim, do paraguaio Velázquez Seiferheld $(2019 ; 2020)$.

Poderíamos estender a pesquisa e, certamente, ampliaríamos essas referências, mas a questão que coloco a partir desse pequeno estado da arte é a que se refere à pergunta: "O que os/as estudantes sabem/entendem sobre o conteúdo Guerra do Paraguai a partir das aulas de história?" Uma breve investigação nos demonstra que essa pergunta não foi até o presente momento uma preocupação central dos/as pesquisadores/as. E, após duas décadas estudando os manuais didáticos de história e a Guerra do Paraguai/Guerra Guasu, essa questão em primordial começou a me inquietar, aliada a outras: "O que os/as estudantes sabem/entendem sobre o conteúdo Guerra do Paraguai a partir dos manuais didáticos de história?"; "O que os/as estudantes sabem/entendem sobre o conteúdo Guerra do Paraguai a partir das fontes e documentos históricos sobre o tema?"; "Estabelecem relação entre o espaço que estão inseridos e os conteúdos sobre a Guerra?; "O conteúdo sobre a Guerra do Paraguai permite ao aluno/a desenvolver uma postura de empatia, sobretudo em relação ao Paraguai?"; "Os/as alunos/as conseguem atribuir sentidos ao conteúdo Guerra do Paraguai?"; e, por fim, "Os/as alunos/as desenvolvem uma compreensão pluriperspectivada sobre o conteúdo Guerra do Paraguai?".

Diante dessas diversas indagações e com o intuito de buscar respostas/pistas/indícios que me levassem a compreendê-las, comecei a desenvolver um Projeto de Pesquisa intitulado "Narrativas da Guerra: ideias de alunos e de manuais escolares de história no Brasil, Paraguai, 
Argentina e Uruguai - o que dizem sobre a Guerra Guasu?" O referido projeto compôs uma proposta mais global que se denomina "Manuais Didáticos de História: patrimônio, movimentos sociais, direitos humanos, gênero, afrodescendentes e indígenas" - autores, textos, usos e leituras e foi desenvolvido entre os anos de 2017 e 2020.

Vale registrar que o contexto no qual se desenvolveu esta pesquisa está marcado pela comemoração dos "150 anos da Guerra do Paraguai/Guerra Guasu", que se constituiu em uma série de ações (simpósios, congressos, colóquios, seminários virtuais, eventos, mostras de cinema, lançamento de filmes, publicação de dossiês, coletâneas e livros, são alguns exemplos) que foram e estão sendo realizadas tanto no Prata, como em outras regiões, no período abarcado pelo anos de 2014 a 2020, respectivamente 150 anos do início e do término do conflito.

Destaca-se que algumas ações de envergadura foram efetivadas como o projeto "Más allá de la guerra" desenvolvido no âmbito do Mercosul, e esse momento histórico expressa algumas questões relevantes: a Guerra do Paraguai/Guerra Guasu, além de se conformar como o maior conflito bélico ocorrido na América Latina, configura-se - no campo de ensino de história - como um dos conteúdos tidos como "temas sensíveis", ou que compõe a Burdening History, conceito elaborado pelo estudioso alemão Von Borries (2018), que de grosso modo referem-se às histórias que deixam como herança um "fardo" ou uma "carga" para as gerações. Assim, como a questão dos escravizados e afrodescendentes no Brasil, as ditaduras civis-militares na América Latina ou o nazismo na Alemanha são temas "delicados" e "sobrecarregados" que as gerações posteriores devem problematizar e superar. No Paraguai, a Guerra Guasu ainda é muito presente na trama histórica nacional e envolve toda a sociedade: militares, civis, intelectuais, políticos, gestores da cultura, artistas etc, em um eterno debate cujos centros são Solano López e a Guerra, Alfredo Stroessner (1954-1989) e ser e defender o Partido Colorado ou o Partido Liberal. Tais processos, cabe pontuar, configuram-se como lutas identitárias, culturais e, também, emocionais. Por outro lado, no Brasil, a Guerra do Paraguai/Guerra Guasu configura-se como um marco na construção histórica nacional, pois se vincula, entre outros fatores, à crise da sociedade brasileira do século XIX, cujo sustentáculo, baseado na monarquia e no sistema escravocrata, viu suas bases ruir no pós-Guerra. Nesse sentido, compreender as tramas tecidas nesse passado histórico recente permite desnudar as redes que se estabelecem, assim como o peso que possuem no tempo presente e lançam luz para uma experiência construtiva do futuro e superação da angústia, da dor e da experiência traumática do coletivo. 


\section{A Guerra do Paraguai: historiografia brasileira em diálogo com as narrativas didáticas de história}

A Guerra do Paraguai, como já afirmado anteriormente, começou a ser divulgada por meio de escritos logo após o seu término e, ao longo do século $\mathrm{XX}$, foi alvo de intensos debates historiográficos acerca de suas construções e interpretações nos distintos países que vivenciaram a contenda. Tais debates calorosos se mantêm até os dias atuais. Em linhas gerais, podemos identificar, no Brasil, três momentos historiográficos que marcaram a referida produção sobre o tema. Destacamos que esse movimento se dá de forma distinta no Paraguai, por exemplo, mas, tendo em vista o espaço para essa reflexão enfocaremos os momentos que marcaram a produção brasileira.

A primeira versão, que denomino de Patriótica, caracteriza-se pelos escritos gestados em seguida ao pós-guerra e elaborados por protagonistas ou não do conflito, assim como por militares, civis e diplomáticos e caracterizaram-se por apresentarem em suas narrativas um forte viés militar, enfatizando os episódios e batalhas ocorridas, como também privilegiando datas e fatos e valorizando a "vitória brasileira" e seus heróis em detrimento da derrota paraguaia. Nessa produção, autores como Rocha Pombo esforçaram-se em criar e difundir imagens que associavam o Paraguai à barbárie, assim como o governante Solano López, com adjetivos que o tipificaram como bárbaro, sanguinário, tirano, megalomaníaco e louco. Tal vertente marcou a escrita da história e das narrativas didáticas de história até meados da década de 1960, o que não significa afirmar que não temos resquícios ainda dessa produção, inclusive no que tange aos manuais didáticos.

Pombo, por exemplo, explicou a eclosão do conflito em função das ambições territoriais e pessoais de Solano López, para o autor:

\footnotetext{
É o ditador do Paraguai, Francisco Solano López, que vai renovar as pretensões de Rosas, de formar no Prata um grande império, rival do Brasil. Para isso preparava-se solícita, mas dissimuladamente; e só aguardava agora, um pretexto para entrar em cena.

Êsse pretexto vai ser a nova intervenção do Império no Estado Oriental, em 1864. $[\ldots] .^{2}$
}

E afirmou ainda: "Para isso é que começa por assustá-lo apoderando-se de um paquete brasileiro [Marquês de Olinda] que ia de Mato Grosso, levando a bordo o coronel Carneiro de Campos $[\ldots]^{\prime 3}$. Sobre as imagens que Rocha Pombo em seus escritos didáticos tinha sobre o que considerava ser o ditador do Paraguai, foram assim descritas: "Solano López era tão cruel que ia deixando o solo, por onde fugia, juncado de cadaveres dos seus próprios amigos e até 


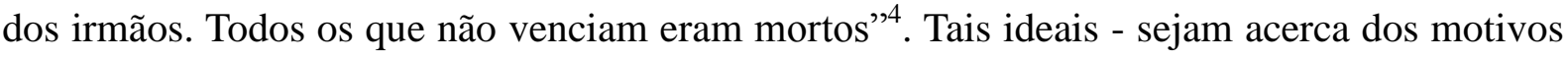
que levaram a eclosão do conflito, seja sobre Solano López e o Paraguai - veicularam corriqueiramente nas produções didáticas brasileiras e, infelizmente, ainda encontramos seus resquícios em alguns manuais didáticos de história.

O segundo momento historiográfico denomino de Imperialista ou Revisionista e exerceu significativo impacto na América Latina a partir da publicação da obra La Guerra del Paraguay - Gran Negócio! do historiador argentino León Pomer, publicada em 1868, e, no Brasil, a partir do lançamento do livro intitulado Genocídio Americano: A Guerra do Paraguai de autoria de Júlio José Chiavenato, ocorrida no ano de 1979. Foi marcada pela influência "marxista" e por um apelo contrário ao imperialismo inglês no Prata e atingiu seu ápice na década de 1970, em meio as ditaduras civis militares que se impuseram na América Latina. Genocídio Americano propagou uma visão sobre a Guerra influenciada por um viés "marxista", anti-imperialista e antianglicano. O conflito, de acordo com este autor, teria ocorrido por interesses econômicos na região platina, especificamente em relação à nação paraguaia. A Inglaterra, que se destacava no cenário mundial, naquele contexto via no Paraguai um entrave para sua expansão e consequente dominação na América Latina. Para Bethell, o conjunto desses estudos configura-se em: “[...] trabalhos revisionistas - sem dúvidas estimulantes, mas nem um pouco convincentes - nos quais o Paraguai aparece como vítima da agressão imperialista e capitalista, constando a Grã-Bretanha como o "Quarto Aliado" na Guerra". 5

A terceira vertente historiográfica nomeio de Neorrevisionista. O eixo interpretativo imperialista sobre a Guerra sofreu uma reconfiguração em meados da década de 1980, fruto entre outras questões dos tempos neoliberais e da instrumentalização do ofício de historiador no Brasil. O domínio efetivo das "ferramentas" do trabalho do/a historiador/a, aliadas à exaustiva pesquisa e análise documental, assim como o acesso a novas fontes e abordagens no processo investigativo e a emergência de novos sujeitos e problemas proporcionaram uma ebulição dos estudos sobre a Guerra do Paraguai/Guerra Guasu.

Nessa seara, o estudioso Moniz Bandeira, em sua obra $\mathbf{O}$ expansionismo brasileiro e a formação dos Estados na Bacia do Prata: da consolidação à Guerra da Tríplice Aliança (1985), foi o primeiro autor a problematizar o eixo explicativo economicista relacionado à Guerra. Para Bandeira, a origem da guerra estava intrinsicamente relacionada à dinâmica do Prata: os problemas e conflitos existentes entre as nações recém-formadas, no caso Brasil, Paraguai, Argentina e Uruguai, eram suficientes para a eclosão do conflito. Alinhados a essas 
perspectivas, muitos/as investigadores/as de diferentes áreas do saber debruçaram-se sobre o tema, como já afirmado, a partir de novos objetos, metodologias, enfoques e abordagens. Velhos temas foram revisitados e outros vieram à baila; diferenciados sujeitos foram visibilizados, ganhando um protagonismo no cenário do conflito em questão. Nessa perspectiva, as análises sobre a Guerra do Paraguai/Guerra Guasu romperam e superaram os tradicionais vieses militar e diplomático.

Autores/as e trabalhos como os de: Sales (1990; 2003), Marques (1995), Sousa (1996), Costa (1996), Silveira (1996), Toral (1999; 2001), Figueira (2001), Doratioto (2002), Izecksohn (2011), Borges e Peraro (2012), Schwarcz (2013), Rodrigues e Pedrosa (2015), Garcia e Arias Neto (2016), Squinelo (2016), Telesca e Squinelo (2019), entre outros, analisaram a Guerra do Paraguai a partir de outras perspectivas e olhares: a formação do exército imperial; a participação dos escravizados no exército; as imagens da Guerra (fotografias, quadros, pinturas, desenhos, litografias, charges, caricaturas etc); papel da imprensa; cinema; cotidiano; comércio; medicina (doenças, enfermarias, hospitais de sangue); desertores e prisioneiros de guerra, tanto brasileiros, como paraguaios; literatura; a participação de mulheres, indígenas, religiosos e crianças etc.

No caso do Paraguai, vale pontuar as obras de: Potthast (1996), Capdevilla (2010), Rodríguez Alcalá (2010), Telesca (2010) e Barreto Valinotti (2013; 2020). O cenário bélico, nessa seara, tornou-se diverso, múltiplo e pluriperspectivado.

\section{Instrumento: investigação, mostra participante e percurso}

O Instrumento de investigação foi elaborado a partir dos problemas que nortearam esta pesquisa e é composto de três partes, a saber: I) Dados de identificação; II) Uso do livro didático de história, um conjunto com 7 (sete) questões; e III) O conceito Guerra do Paraguai, também com 7 (sete) questões. Nestas que se referem ao conceito Guerra do Paraguai/Guerra Guasu, elaboramos 3 (três) questões com perguntas de respostas abertas, 1 (uma) com um trecho da música Sonhos Guaranis de autoria de Almir Sater e Paulo Simões (Fonte A), 1 (um) fragmento da obra Reminiscências da Campanha do Paraguai, escrita pelo militar Dionísio Cerqueira (Fonte B) e que versa sobre a presença de mulheres nos campos de batalha da Guerra, 1 (uma) Fotografia de dois soldados indígenas, um Terena e o outro Kadiwéu (Fonte C), que lutaram na Guerra e de autoria e datas desconhecidas e 1 (uma) Ilustração de Angelo Agostini, que foi publicada no jornal Vida Fluminense no ano de 1870, que se denomina De volta ao Paraguai (Fonte D) e constitui-se em uma crítica à participação negra 
escravizada na Guerra e às contradições do sistema escravocrata que marcaram a vida desses combatentes.

Entre os meses de novembro e dezembro do ano de 2017, foram aplicados 151 (cento e cinquenta e um questionários) em 5 (cinco) escolas públicas no estado de Mato Grosso do Sul, sendo 2 (duas) escolas estaduais, 2 (duas) municipais e 1 (uma) indígena, situadas em 4 (quatro) municípios: Anastácio, Aquidauana, Campo Grande e Dourados. O instrumento foi aplicado em 9 (nove) turmas: 8 (oito) turmas de $8^{\circ}$ ano e 1 (uma) turma de $7^{\circ}$ ano. De acordo com o currículo escolar brasileiro, o conteúdo acerca da Guerra do Paraguai, no Ensino Fundamental II, é abordado no $2^{\circ}$ semestre de cada ano letivo, no $4^{\circ}$ e último bimestre do ano; nesse sentido, o instrumento de investigação foi aplicado após cada turma já ter trabalhado o conteúdo em sala de aula. Conforme acordado com as/os professoras/es das respectivas turmas, a investigadora se apresentou em cada escola em data e hora marcados e, após sua apresentação, explanou aos alunos/as sobre o que se referia o questionário e, em sequência, procedeu à aplicação do instrumento de investigação.

Ressalta-se que nessa reflexão o nome das escolas que compuseram a mostra da pesquisa está referido por meio de pseudônimos de sujeitos que protagonizaram e vivenciaram aspectos da Guerra do Paraguai/Guerra Guasu. Outrossim, a identidade dos/as estudantes está resguardada e o depoimento deles quando citado será feito pelas iniciais do nome e sua idade será arrolada.

Quadro 1: Mostra participante: Escolas

\begin{tabular}{|c|l|l|l|}
\hline \multicolumn{1}{|c|}{ ESCOLA } & \multicolumn{1}{|c|}{ LOCALIZAÇÃO } & \multicolumn{1}{c|}{ ESFERA } \\
\hline 1 & Visconde de Taunay & Campo Grande/MS & Municipal \\
\hline 2 & Jovita & Dourados/MS & Municipal \\
\hline 3 & Tenente Lili & Dourados/MS & Estadual \\
\hline 4 & Dona Senhorinha & Aquidauana/MS & Estadual \\
\hline 5 & Antônia & Anastácio/MS & Estadual Indígena \\
\hline
\end{tabular}

Fonte: Elaborado pela autora. 
Quadro 2: Mostra participante: alunos/as

\begin{tabular}{|c|c|}
\hline $\begin{array}{c}\text { TOTAL DE } \\
\text { ALUNOS/AS }\end{array}$ & $\mathbf{1 5 1}$ \\
\hline FEMININO & 82 \\
\hline MASCULINO & 69 \\
\hline 12 ANOS & 2 \\
\hline 13 ANOS & 54 \\
\hline 14 ANOS & 56 \\
\hline 15 ANOS & 22 \\
\hline 16 ANOS & 11 \\
\hline 17 ANOS & 2 \\
\hline
\end{tabular}

Fonte: Elaborado pela autora.

Esclarecemos que no instrumento de investigação na parte I que se refere à Identificação no item "Gênero" foram dadas como opções a serem assinaladas a de masculino, feminino e outros, entretanto nenhum depoente assinalou a opção "outros"; pontuamos, ainda, que há uma diferença entre o número de participantes total e a distribuição das idades, pois mais de um depoente não declarou sua idade.

As cinco escolas que compuseram o locus da investigação, por serem públicas, estão submetidas ao processo de escolha do Livro Didático conforme o disposto pelo Plano Nacional do Livro Didático (PNLD); no período a que se refere esta pesquisa as Coleções Didáticas adotadas estão dispostas no Quadro 3:

Quadro 3: Coleção Didática de História adotadas nas escolas e o conceito Guerra do Paraguai

\begin{tabular}{|c|c|c|c|c|c|}
\hline & TÍTULO & AUTOR/A & $\begin{array}{l}\text { EDIÇÃO/ } \\
\text { CIDADE }\end{array}$ & $\begin{array}{c}\text { EDITO } \\
\text { RA/ } \\
\text { ANO }\end{array}$ & $\begin{array}{l}\text { CONCEITO GUERRA } \\
\text { DO PARAGUAI }\end{array}$ \\
\hline 1 & $\begin{array}{l}\text { Projeto } \\
\text { Araribá }\end{array}$ & $\begin{array}{l}\text { Obra } \\
\text { coletiva } \\
\text { concebida, } \\
\text { desenvolvid } \\
\text { a e } \\
\text { produzida } \\
\text { pela Editora } \\
\text { Moderna }\end{array}$ & São Paulo & $\begin{array}{l}\text { Moderna } \\
2014 \\
4^{\mathrm{a}} \text { ed. }\end{array}$ & $\begin{array}{l}\text { Unidade } 8-\text { Brasil: da } \\
\text { Regência ao Segundo } \\
\text { Reinado } \\
\text { Tema } 2-\text { O jovem D. } \\
\text { Pedro II no trono do } \\
\text { Brasil } \\
\text { A Guerra do Paraguai } \\
\text { (1864-1870) } \\
\text { Página 196 }\end{array}$ \\
\hline 2 & Historia.Doc & $\begin{array}{l}\text { Ronaldo } \\
\text { Vainfas } \\
\text { Jorge } \\
\text { Ferreira } \\
\text { Sheila de } \\
\text { Castro Faria }\end{array}$ & São Paulo & $\begin{array}{l}\text { Saraiva } \\
2015 \\
1^{\mathrm{a}} \text { ed. }\end{array}$ & $\begin{array}{l}\text { Unidade } \mathbf{5}-\text { Escravidão } \\
\text { e liberdade } \\
\text { Capítulo } \mathbf{1 5}-\text { Crise da } \\
\text { escravidão e da } \\
\text { monarquia no Brasil } \\
\text { A monarquia e o }\end{array}$ \\
\hline
\end{tabular}




\begin{tabular}{|l|l|l|l|l|l|}
\hline & $\begin{array}{l}\text { Daniela } \\
\text { Buono } \\
\text { Calainho }\end{array}$ & & & $\begin{array}{l}\text { Paraguai } \\
\text { A Guerra do Paraguai } \\
\text { Páginas 247 a 249 }\end{array}$ \\
\hline 3 & Historiar & $\begin{array}{l}\text { Gilberto } \\
\text { Cotrim } \\
\text { Jaime } \\
\text { Rodrigues }\end{array}$ & São Paulo & $\begin{array}{l}\text { Saraiva } \\
2018 \\
3^{\text {a }} \text { ed. }\end{array}$ & $\begin{array}{l}\text { Capítulo 11 - Segundo } \\
\text { Reinado } \\
\text { O conteúdo Guerra do } \\
\text { Paraguai não foi } \\
\text { abordado }\end{array}$ \\
\hline 4 & $\begin{array}{l}\text { Projeto } \\
\text { Mosaico }\end{array}$ & $\begin{array}{l}\text { Cláudio } \\
\text { Vicentino } \\
\text { José Bruno } \\
\text { Vicentino }\end{array}$ & São Paulo & $\begin{array}{l}\text { Scipione } \\
2015 \\
\text { Módulo 8 - Brasil e o } \\
\text { fim da Monarquia } \\
\text { Capítulo 16-A política } \\
\text { no Segundo Reinado } \\
\text { As guerras na bacia do } \\
\text { rio da Prata } \\
\text { A Guerra do Paraguai } \\
\text { Páginas 284-290 }\end{array}$ \\
\hline
\end{tabular}

Fonte: Elaborado pela autora.

Embora as quatro coleções didáticas sejam diferentes, é possível averiguar que possuem aspectos comuns. Apesar de incorporarem fontes distintas, como mapas, charges e fotografia, apresentam ainda um eixo explicativo tradicional sobre o conflito; as discussões historiográficas pertinentes ao tema quando existente são superficiais e genéricas, assim como o conteúdo sobre a Guerra ano a ano perde espaço entre as coleções, chegando em algumas situações a ocupar 1 página, como é o caso do Projeto Araribá, ou mesmo a própria ausência do conteúdo, conforme expresso na Coleção Didática Historiar. Em relação às questões que explicariam a diminuição quantitativa da abordagem do conteúdo Guerra do Paraguai que vem ocorrendo desde os anos 1990, têm-se algumas pistas, mas não se constituem objeto dessa reflexão.

\section{Instrumento: análise das narrativas históricas dos/as estudantes}

Após a leitura, tabulação e análise dos 151 (cento e cinquenta e um) questionários aplicados, sistematizamos as principais ideias contidas nas narrativas históricas dos/as estudantes, conforme quadro abaixo: 
Quadro 4: Principais narrativas históricas expressas pelos/as estudantes

\begin{tabular}{|c|c|}
\hline INDAGAÇÕES & NARRATIVAS HISTÓRICAS \\
\hline $\begin{array}{l}\text { ANTECEDENTES } \\
\text { (CAUSAS) DO } \\
\text { CONFLITO }\end{array}$ & $\begin{array}{l}\text { - Ultimatum emitido por Francisco } \\
\text { Solano López para d. Pedro II } \\
\text { ("Carta" que d. Pedro II não } \\
\text { respondeu, o que motivou a eclosão } \\
\text { do conflito). } \\
\text { - Necessidade do Paraguai em } \\
\text { expandir seus territórios. } \\
\text { - Necessidade do Paraguai de ter } \\
\text { livre acesso a Bacia do Prata. } \\
\text { - Intervenção do Brasil no Uruguai. } \\
\text { - "Loucura" de Francisco Solano } \\
\text { López, governante paraguaio. } \\
\text { - Desenvolvimento do Paraguai em } \\
\text { relação aos outros países do Prata. } \\
\text { - Interesse inglês. } \\
\text { - "Invasão" paraguaia em territórios } \\
\text { brasileiros. }\end{array}$ \\
\hline $\begin{array}{l}\text { PARTICIPAÇÃO } \\
\text { FEMININA }\end{array}$ & $\begin{array}{l}\text { Adjetivos: } \\
\text { - Corajosa, } \\
\text { - Valente, } \\
\text { - Sem medo. } \\
\text { Associada à ideia de: } \\
\text { - Auxílio, } \\
\text { - Assistência, } \\
\text { - Ajuda, } \\
\text { - Cuidado, } \\
\text { - Necessidade de proteção. } \\
\text { (Neste caso, aos maridos e aos } \\
\text { soldados) }\end{array}$ \\
\hline $\begin{array}{l}\text { PARTICIPAÇÃO } \\
\text { INDÍGENA }\end{array}$ & $\begin{array}{l}\text { - Integraram o exército brasileiro } \\
\text { para lutarem por suas terras. } \\
\text { - Integraram o exército brasileiro } \\
\text { para defenderem suas terras. } \\
\text { - Integraram o exército brasileiro } \\
\text { para salvarem suas terras. } \\
\text { - Ideia de bravura e honra. }\end{array}$ \\
\hline $\begin{array}{l}\text { PARTICIPAÇÃO } \\
\text { NEGRO } \\
\text { ESCRAVIZADO }\end{array}$ & $\begin{array}{l}\text { - Se alistaram no exército brasileiro } \\
\text { para conseguir a Carta de Alforria. }\end{array}$ \\
\hline $\begin{array}{l}\text { ORIENTAÇÃO } \\
\text { TEMPORAL }\end{array}$ & $\begin{array}{l}\text { - A guerra durou muitos anos... } \\
\text { - A guerra durou entre } 4,6,8 \text { e } 10 \\
\text { anos... } \\
\text { - Não localização nos anos e século: } \\
\text { de } 1864 \text { a } 1870 \text {, século XIX. } \\
\text { - Não se localizam na linha do } \\
\text { tempo (acontecimentos, período, }\end{array}$ \\
\hline
\end{tabular}




\begin{tabular}{|c|c|}
\hline & personagens, tempo e espaço...). \\
\hline $\begin{array}{l}\text { RESULTADOS } \\
\text { (CONSEQUENCIAS) } \\
\text { PARA O BRASIL }\end{array}$ & $\begin{array}{l}\text { - Perdas humanas. } \\
\text { - Aquisição de dívidas. }\end{array}$ \\
\hline $\begin{array}{l}\text { RESULTADOS } \\
\text { (CONSEQUENCIAS) } \\
\text { PARA O } \\
\text { PARAGUAI }\end{array}$ & $\begin{array}{l}\text { - Perdas territoriais; } \\
\text { - Perdas humanas; } \\
\text { - Tornou-se } \\
\text { economicamente; } \\
\text { - Adquiriu dívidas; } \\
\text { - Ficou pobre; } \\
\text { - Sofre as consequências até os dias } \\
\text { atuais. }\end{array}$ \\
\hline $\begin{array}{l}\text { RESULTADOS } \\
\text { (CONSEQUÊNCIAS) } \\
\text { PARA A } \\
\text { ARGENTINA } \\
\end{array}$ & - Aquisição de dívidas. \\
\hline $\begin{array}{l}\text { RESULTADOS } \\
\text { (CONSEQUENNCIAS) } \\
\text { PARA O URUGUAI }\end{array}$ & $\begin{array}{l}\text { - Nenhum impacto, pois sua } \\
\text { participação foi pequena, inclusive } \\
\text { o número de efetivo militar. }\end{array}$ \\
\hline
\end{tabular}

Fonte: Elaborado pela autora.

\section{Antecedentes da Guerra}

Foi uma guerra que aconteceu, por ignorância de d. Pedro, Ele não respondeu a Carta de Solano López. Devia ter respondido para evitar a guerra. A guerra deixou suas consequências: um

Brasil endividado e um Paraguai com menos da metade da população. Na minha opinião a Bacia poderia ser usada facilmente pelos dois, uma conversa bastaria. (YCJ, 13 anos)

No que se refere aos antecedentes da Guerra, a explicação que mais esteve presente nas narrativas dos/as alunos/as foi a que relaciona a eclosão do conflito com as supostas ambições territoriais do Paraguai e os problemas que envolviam a livre navegação no Prata. No que é pertinente à disputa pela Bacia Platina por Paraguai, Brasil, Uruguai e Argentina, a narrativa a seguir exemplifica a questão:

A Guerra do Paraguai foi o maior conflito armado na América do Sul, que teve a participação de quatro grandes nações, sendo elas: Paraguai, Brasil, Argentina e Uruguai. A guerra aconteceu porque o Paraguai precisava chegar ao mar para exportar seus produtos para outros países, mas como o Paraguai não tinha saída para o mar tinha que invadir o território brasileiro ou argentino para chegar até o mar, mas como Brasil e Argentina não queriam que isso acontecesse tiveram que começar a guerra, mas como não conseguiram vencer a guerra sozinhos chamaram o Uruguai e formaram a Tríplice Aliança, assim vencendo o Paraguai. ${ }^{6}$ 
A defesa de que um dos motivos que levaram à Guerra também se relacionava aos territórios litigiosos entre Brasil e Paraguai e Paraguai e Argentina também foi elencada em algumas respostas: "O Brasil e a Argentina queriam a posse de um território, e o Paraguai também, então entraram em uma guerra. O Brasil e a Argentina assumiram o controle do

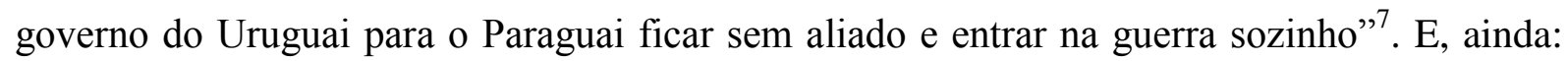
"Entendo que a Guerra do Paraguai aconteceu porque Solano López queria um território do Brasil e o povo não queria deixar então, Brasil, Argentina e Uruguai se juntaram”.

Essa narrativa histórica dos eventos que desembocaram na Guerra do Paraguai/Guerra Guasu está em sintonia com o movimento da historiografia contemporâneo e mais atualizado e que situamos como neorrevisionista, entretanto, elementos dos dois outros momentos historiográficos, ainda que em menor medida, foram citados. Sobre a construção pejorativa da figura de Solano López empreendida por Rocha Pombo e que o relaciona como um megalomaníaco que sonhava em dominar o Prata, registramos os depoimentos: “A Guerra do Paraguai não foi algo bom, milhares de pessoas e crianças morreram, Francisco Solano López era um louco $[\ldots]]^{\prime 9}$. Assim como:

A Guerra do Brasil e Paraguai, para mim foi interessante, pelo motivo do Paraguai querer tomar terra do Brasil achando que ia ser fácil; começou a saquear o Brasil pelo Sul e, depois o Brasil fez uma união entre Brasil, Uruguai, Argentina formando a aliança que se voltou contra Solano López que tinha fama de louco. ${ }^{10}$

Em parte das narrativas históricas a figura de Francisco Solano López é vista por meio de vários olhares: ora o governante paraguaio é um louco, ora é um ambicioso, ora é um Ditador, ora é alguém que incorpora todas essas facetas, e pelo conjunto desses atributos é responsabilizado e culpabilizado pelo conflito:

A Guerra do Paraguai teve início no ano de 1864, a partir da ambição do ditador Francisco Solano López que tinha como objetivo aumentar o território paraguaio e obter uma saída para o Oceano Atlântico através dos rios da Bacia do Prata. Ele inicia o confronto com a criação de inúmeros obstáculos: impostos às embarcações brasileiras que se dirigiam a Mato Grosso através da capital do Paraguai. ${ }^{11}$

Em uma das narrativas, dois pontos merecem destaque: 1) a associação da eclosão do conflito com o aprisionamento do paquete brasileiro Marquês de Olinda: "o que causou isso [a Guerra] foi que eles [paraguaios] invadiram o Mato Grosso e a embarcação roubada Marquês de Olinda contribuíram para a guerra ter início"12 e, 2) a conexão com ideias expressas pela vertente imperialista: “[...] quem saiu ganhando fazendo um 'bom negócio' foram os ingleses que emprestaram dinheiro e até armamentos [...]"13; em outra narrativa a 
ideia imperialista também é apontada: “A Tríplice Aliança foi financiada boa parte pela

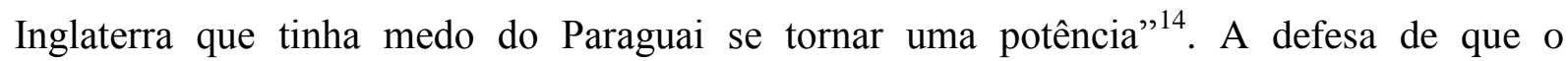
aprisionamento do Marquês de Olinda - embarcação que transportava Frederico Carneiro de Campos até a província de Mato Grosso com vistas a tomar posse como presidente daquela Província, efetivada pelos paraguaios - teria sido o principal motivo da eclosão do conflito foi a tese defendida após o término da contenda e em grande parte do século XX e esteve presente nos manuais didáticos de história, como os de Pombo e Macedo e formaram gerações de estudantes.

Por outro lado, o escopo que atribuiu à Inglaterra toda a culpabilidade pela Guerra do Paraguai/Guerra Guasu, defendido pela vertente imperialista, também teve ecos nas narrativas didáticas de história, sobretudo a partir dos anos 1970, como exemplo, citamos as coleções: Brasil Vivo, História da sociedade brasileira e, História: os caminhos do homem. Vale ressaltar que mesmo dentro dos quadros impostos pelo Plano Nacional do Livro Didático (PNLD), há coleções didáticas de história que ainda possuem resquícios dessas vertentes, ou que, em um parágrafo ou em um box explicativo, apresentam aos/as estudantes as três versões historiográficas sobre o conflito platino. Nesse caso, cabe ao/a professor/a dominar o debate historiográfico pertinente ao tema com vistas a conduzir a discussão de uma forma profícua ou o/a educando/a assimila (quando assimila) essas variadas informações sem necessariamente compreendê-las e/ou atribuir-lhes sentido.

Nessa seara, registramos ainda que algumas narrativas apontam que a causa maior que levou à eclosão da Guerra foi a intervenção brasileira no Uruguai, fato ocorrido no ano de 1864 e em defesa do Partido Colorado, aliado ao fato de que o Imperador d. Pedro II não teria respondido à "Carta" enviada por Francisco Solano López. A Carta refere-se ao ultimatum enviado pelo governante paraguaio em 30 de agosto de 1864, no qual advertia d. Pedro II que uma intervenção militar significaria a quebra de equilíbrio de poder no Prata o que levaria López, filho, a declarar guerra ao Império; tal cenário histórico foi assim descrito:

A Guerra do Paraguai, foi um acontecimento histórico do Brasil, Paraguai, Argentina e Uruguai.

A guerra começou porque o Paraguai enviou uma carta a d. Pedro II [e este] não a respondeu. Paraguai revidou atacando o Brasil, e o Paraguai queria invadir Uruguai, mas para isso Argentina não deixou Uruguai passar, e com isso Brasil, Argentina e Uruguai se aliaram contra o Paraguai. Brasil levou homens juntos com Uruguai e Argentina, atacaram o Paraguai e fizeram um acampamento no território do Paraguai, e Paraguai aniquilou as tropas do Brasil, Uruguai e Argentina e, depois Brasil preparou 30 mil homens, Uruguai 5 mil e Argentina 5 mil, e juntos aniquilaram quase todos os paraguaios e mataram Solano López e o filho dele que foi para a Guerra. ${ }^{15}$ 
De uma forma geral, um ponto comum das narrativas refere-se ao reconhecimento da assinatura do Tratado da Tríplice Aliança ocorrido em $1^{\circ}$ maio de 1865 e firmado entre Brasil, Argentina e Uruguai e, que tal acordo e junção de forças foram o que possibilitou a derrota do Paraguai. Embora os/as estudantes expliquem em suas narrativas históricas os antecedentes da Guerra do Paraguai/Guerra Guasu a partir de diferentes e distintos prismas, reconhecem que o conflito significou uma derrota sem precedentes para a nação paraguaia, apontando, sobretudo, um número elevado de mortes (homens, mulheres, idosos e crianças), um crescente endividamento e dependência econômica, assim como uma significativa perda territorial.

\section{Protagonistas subalternos - a participação feminina nos campos de batalha da Guerra Guasu}

As mulheres lutaram na Guerra, mas poucos sabem disso.

(LM, 15 anos)

A historiadora de gênero Ana Barreto Valinotti vem demonstrando, ao longo de seus estudos, os distintos e diferenciados espaços que a mulher ocupou ao longo da longeva contenda que se constituiu a Guerra do Paraguai/Guerra Guasu. No campo, na cidade, no comércio, no palco da guerra, na saúde, em "associações", voluntariando-se, entre tantos outros ambientes, público e/ou privado, a mulher exerceu seu papel de protagonista e não apenas um papel de mero "apêndice" ao homem. Em relação aos cuidados dos enfermos que tradicionalmente é vinculada a atuação da mulher na Guerra, Barreto Valinotti registrou que:

\footnotetext{
Además del rol de asistir caritativamente a los desvalidos, para 1865 cuando se instalaron hostipales en el Paraguay para atender a los heridos que llegaban a la capital de los diferentes frentes, la labor de las mujeres en los hospitais operaba en distintas direcciones. Algunas tenían un sueldo como assistentes de los cirujanos, pero la mayor parte venía voluntariamente a asistir sus hijos, esposos e padres. ${ }^{16}$
}

No Brasil, é conhecida a história de Anna Néry que, no contexto da Guerra do Paraguai, com o intuito de acompanhar seus filhos e seu irmão solicitou o direito de acompanhá-los ao front de guerra, tendo seu pedido atendido e sendo incorporada ao décimo batalhão de voluntários em agosto de 1865, na qualidade de enfermeira. Vale registar, ainda, o caso de Jovita Alves Feitosa, cuja biografia escrita por José Murilo de Carvalho: Jovita Alves Feitosa: voluntária da pátria, voluntária da morte, lançada em 2019, demonstra como a jovem Jovita desejava se voluntariar para a Guerra do Paraguai, mas, ao contrário de Anna Néry, não aceitou a incorporação como enfermeira, tendo seu sonho frustrado por não poder 
combater como um soldado nas trincheiras. A ideia de cuidado relacionado à mulher durante os episódios ocorridos no conflito guarani acabaram ao longo da história sendo reforçada e reproduzida pela historiografia oficial, entretanto outros olhares estão sendo lançados sobre as fontes, oferecendo abordagens que demonstram que a mulher desempenhou inúmeros papéis e ocupou diferenciados espaços durante a Guerra:

[...] es importante partir de la ideia de que la mobilización general de varones decretada em 1866, las mujeres comenzaron a desempeñar roles que, si bien no les eran desconocidos, les significaron atividades adicionales a las del cuidado, por exemplo, el comercio y los negócios con el Estado. Igualmente, aún cuando historicamente la mujer en el Paraguay desempeñó roles agrícolas, el crecimiento de las exigências de alimentación durante la guerra también aumento la carga laboral sobre las mujeres agricultoras, ya que se debía aumentar constanmente el volumen de producción de alimentos para las tropas, sin descuidar el alimento doméstico. ${ }^{17}$

Barreto Valinotti, em seus estudos, demonstrou, por exemplo, que as mulheres consideradas por Francisco Solano López como "traidoras" e as "residentas", exerceram as mais variadas atividades no âmbito da Guerra. Assim relatou:

Un día normal em un pueblo de residentas, no solo cordillerano sino también guaireño, como Valenzuela, Unión, Barrero Grande o Hyaty (hoy Félix Pérez Cardozo) empezaba casi siempre de la misma manera, tal como al início de la guerra. Los trabajos se dividían a criterio del jefe politico o del juez de Paz, podían ser el labrado de las chacras; el cuidado de sembradíos; la colecta de frutas, verduras y legumbres; el hilado com fibras de coco o de caraguatá; el teñido; la confección de uniformes (las telas de algodón ya no existían y se hacían con las otras fibras naturales; la preparación de cigarros, dulces, harinas e alcoholes. Todas las labores seguían un plan estabelecido. Por un lado, estaba el trabajo que asseguraba la comida a cada una de las familias, y por outro, el que debía mantener las provisiones que el ejército necesitaba. ${ }^{18}$

Embora as mulheres tenham sido, portanto, protagonistas em inúmeras situações e responsáveis diretas por movimentar atividades intrinsicamente relacionadas à criação e condições para o desenrolar e a manutenção do conflito, as narrativas históricas dos/as estudantes, no que tangem à participação e presença feminina nos campos de batalha da Guerra do Paraguai/ Guerra Guasu, convergem para as mesmas explicações, isto é, não ignoram a presença feminina no desenrolar do conflito, apontando que essas mulheres eram "valentes", “corajosas" e não "possuíam medo", entretanto tais qualidades positivadas são associadas à ideia da mulher como o "sexo frágil", vulnerável e delicado, por isso elas necessitavam de "auxílio", "assistência", “ajuda", "cuidado" e "proteção" que deveriam ser oferecidos pelos seus maridos ou por soldados, jamais por uma outra mulher. 
Fonte B - Trecho da obra Reminiscências da Campanha do Paraguai

Essas mulheres que seguiam o exército não tinham medo de coisa alguma. Iam às avançadas mais perigosas levar a bóia dos maridos. Nas linhas de atiradores que combatiam encarniçados, vi-as mais de uma achegarem-se aos feridos, rasgarem as saias em ataduras para lhes estancarem o sangue, montá-los na garupa dos seus cavalos e conduzi-los no meio das balas para os hospitais. Algumas trocavam as amazonas por bombachos nos dias de combate, e as pontas das suas lanças formavam os salientes nas cargas e seus regimentos.

(Dionísio Cerqueira, Reminiscências da Campanha do Paraguai, 1865-1870, 1870)

Fonte: Instrumento de Investigação. Projeto: Narrativas da guerra: ideias de alunos e de manuais escolares de história no Brasil, Paraguai, Argentina e Uruguai - o que dizem sobre a Guerra Guasu? 2017.

De acordo com uma das narrativas, na esfera da Guerra do Paraguai, as mulheres: “[...] ajudavam bastante e cuidavam de seus maridos durante a Guerra, que não tinham medo. Levavam os maridos até hospitais por causa dos ferimentos de bala. Essas mulheres eram muito corajosas e valentes" 19 . Em outra afirma-se que: "As mulheres do exército eram muito corajosas, levavam boia fria para seus maridos. Essas mulheres faziam de tudo para os seus maridos. Rasgavam as saias em ataduras para lhes salvarem. Montavam em seus cavalos e levavam para os hospitais". ${ }^{20}$

Embora tangenciem, também, a ideia de cuidado a ser oferecido pela mulher, duas narrativas chamam a atenção, pois relacionam as mulheres a adjetivos como "ousadas" e "valentes": "Muitas mulheres levaram almoço para seus maridos, o que na minha opinião deixaram elas em risco, elas até rasgaram suas roupas para estancar o sangue de seus maridos; eram ousadas",21. Em outra narrativa e, em relação a Fonte B o/a estudante relatou que:

Retrata como era a realidade da guerra. A forma que as mulheres, esposas de soldados, tiveram a sua participação na guerra, informando que o seu papel foi muito importante para os combates. O texto retrata o quão valente eram e, as dificuldades que enfrentavam no campo de batalha. ${ }^{22}$

Nesse sentido, ficou expresso que os/as estudantes não visualizam a possibilidade da mulher protagonizar um ambiente tradicionalmente tido como masculino, não há concebem como soldado/combatente no contexto e cotidiano da Guerra do Paraguai/Guerra Guasu, tampouco estabelecem conexões de que as mulheres tiveram presentes em distintos espaços, 
produzindo, trabalhando, vendendo produtos, gerindo propriedades, etc, para que fosse possível a manutenção e andamento da Guerra.

\title{
Protagonistas subalternos - a participação negra escravizada e liberta no front da Guerra Guasu
}

\section{[...] o Brasil tinha os escravos que foram para a Guerra e se os escravos voltassem vivos eles iriam ganhar uma Carta de Alforria que ele ia ser livre [...]} (VFDS, 15 anos)

A participação negra escravizada e livre na formação do exército brasileiro foi objeto de estudo, no Brasil, de pesquisadores como Salles (1990) e Sousa (1996). À época, tais investigações trouxeram contribuições significativas para o tema, na medida em que desmitificaram a ideia de que o exército imperial era formado exclusivamente por negros escravizados. Tais autores comprovaram que o contingente humano recrutado em meio à guerra foi composto por negros escravizados, cidadãos livres e membros das camadas populares. Para Salles: "Nas condições da época, o engajamento forçado de indivíduos das camadas populares era a forma usual de abastecer o exército de material humano" ${ }^{\text {"23 }}$. Isso não quer dizer que negros escravizados não compuseram as fileiras dos exércitos envolvidos em combate:

\begin{abstract}
Soldados negros, ex-escravos ou não, lutaram em pelo menos três dos quatro exércitos dos países envolvidos. Os exércitos paraguaio, brasileiro e uruguaio tinham batalhões formados exclusivamente por negros. Como exemplos temos o Corpo dos Zuavos da Bahia e o batalhão uruguaio Florida. Escravos propriamente ditos, engajados como soldados, lutaram comprovadamente nos exércitos paraguaio e brasileiro. ${ }^{24}$
\end{abstract}

Entretanto, a promulgação do Decreto dos Voluntários da Pátria, ocorrido em janeiro de 1865 com vistas ao recrutamento (forçado) para a formação dos Corpos de Voluntários da Pátria, gerou uma série de situações peculiares de alistamento militar. Sobre o tema, Salles apontou que:

É bom registrar que a prática de se apresentar um substituto para o serviço militar, principalmente na Guarda Nacional, era relativamente comum na época (e não apenas no Brasil). O substituto, inclusive, não precisava ser necessariamente um escravo. Cidadãos livres, em troca de vantagens, favores e compensação financeira, aceitavam apresentar-se como substitutos de outros cidadãos. ${ }^{25}$

Nesse sentido, inúmeros dispositivos foram empregados para "driblar" o recrutamento forçado imposto pelo Decreto dos Voluntários da Pátria: 
Os cidadãos do império dispunham de diversas formas de se esquivarem da convocação. Os mais aquinhoados, utilizavam-se de doações de recursos, equipamentos, escravos e empregados à Guarda Nacional e aos Corpos de Voluntários para lutarem em seu lugar; os que podiam menos, faziam oferecimento de familiares, ou seja, alistavam seus parentes, filhos, sobrinhos, agregados etc. Aos despossuídos não restava outro recurso para escapar ao alistamento que a fuga para o mato. ${ }^{26}$

E ainda:

A compra de substitutos, ou seja, a compra de escravos para lutarem em nome de seus proprietários, tornou-se prática corrente. Sociedades patrióticas, conventos e o governo encarregavam-se, além disso, da compra de escravos para lutarem na guerra. O império prometia alforria para os que se apresentassem para a guerra, fazendo vista grossa para os fugidos. ${ }^{27}$

A promessa de liberdade (Carta de Alforria) levou muitos negros escravizados a atenderem ao chamado do voluntariado e as narrativas históricas dos/das estudantes associam a presença negra no exército imperial (Fonte D) a este aspecto: o da possibilidade de adquirir a liberdade: "Pois os donos de terra com medo de lutar enviavam o escravo para lutar e se voltasse vivo ganhava a liberdade e, com isso, muitos escravos ganhavam a liberdade" ${ }^{28}$. Dois estudantes apontaram em suas narrativas a questão da escravidão existente no Império e as suas contradições: "Que ainda o Brasil estava em escravidão na Guerra do Paraguai"29 . E, "O soldado negro volta da guerra e ele volta livre para o Brasil, mas consequentemente no Brasil ainda há escravidão, ele se lamenta, pois a escravidão não havia sido abolida" ${ }^{30}$ 
Fonte D - Ilustração de Angelo Agostini publicada no jornal Vida Fluminense no ano de 1870

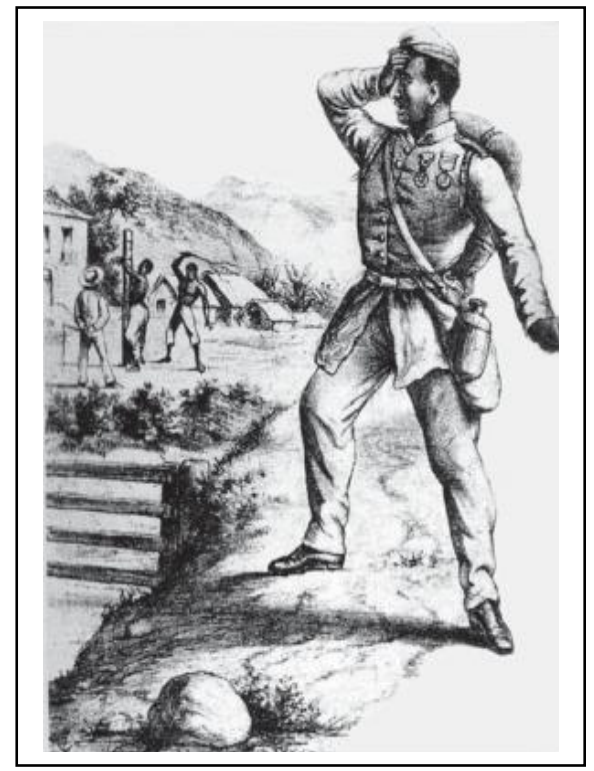

Fonte: Instrumento de Investigação. Projeto:

Narrativas da guerra: ideias de alunos e de manuais escolares de história no Brasil, Paraguai, Argentina e Uruguai - o que dizem sobre a Guerra Guasu?, 2017.

No que se refere à questão da participação negra escravizada apontada pelos/as estudantes, Salles chamou a atenção para o seguinte ponto:

O escravo soldado, voluntário de fato, oferta patriótica de seu senhor, substituto, africano sob custódia do governo, foi uma realidade. Se sua presença não foi majoritária nos efetivos militares, foi marcante e significativa. ${ }^{31}$

E, ainda de acordo com seus estudos: “[...] os escravos representariam 5,49\% do total [das fileiras do exército]".32

A Fonte D foi a menos explorada pelos/as estudantes; uma parte significativa deles sequer respondeu a ela, o que permite apontar que, infelizmente, o estudo sobre os protagonistas subalternizados no ensejo da Guerra do Paraguai/Guerra Guasu ainda se constitui em seara menosprezada, seja pelas narrativas didáticas de história, seja pela falta de domínio do/a professor/a em relação aos estudos sobre o tema.

\section{Protagonistas subalternos - a participação indígena no teatro de operações Da Guerra Guasu}


Porque os indígenas foram os únicos que ficaram e lutaram por suas terras... (ABF, 16 anos)

A participação das etnias indígenas brasileiras no contexto da Guerra do Paraguai constituiu-se em objeto de estudo de alguns estudiosos/as, como exemplo citamos: Oliveira e Pereira (2007), que refletiram sobre a etnia Terena; Esselin e Vargas (2015,) que analisaram as etnias Terena, Guaicuru, Kaiowa e outras; e, finalmente, Silva (2018), que se dedicou aos Kadiwéu.

Os estudos em questão apontam em comum a relevante e imprescindível participação das etnias indígenas como protagonistas no cenário da ocupação da Província de Mato Grosso pelos paraguaios. Naquela situação, indígenas se uniram às forças imperiais, objetivando defender e assegurar as terras em que viviam. Foram fundamentais ao disponibilizarem seus conhecimentos geográficos à coluna expedicionária que rumou ao sul de Mato Grosso com o intuito de expulsar as tropas paraguaias; prestaram inúmeros serviços as tropas imperiais: abriam trilhas e picadas; orientavam os soldados na região, pois conheciam as matas, rios, serras, acidentes geográficos etc; abasteceram a coluna de mantimentos, na medida que praticavam a agricultura de subsistência; armaram emboscadas contra os soldados paraguaios, entre outros.

O conhecimento geográfico que as etnias indígenas possuíam da região foram de suma importância para a Coluna Expedicionária, que se encontrava estacionada na região dos Morros:

Devido ao conhecimento geográfico do território, os nativos foram importantes informantes, permitindo com seus relatos que as autoridades imperiais monitorassem os movimentos dos paraguaios em todo o período da invasão, mesmo que não tivesse sido feito muito com essa informação para a reconquista do território. ${ }^{33}$

No que se relaciona ainda ao protagonismo indígena no contexto da Guerra do Paraguai/Guerra Guasu, os autores destacaram também que:

A infeliz coluna imperial ainda teve que contar com a ajuda dos nativos como tradutores e guias. Os engenheiros que participaram do conflito elaboraram a carta do território sul-mato-grossense, examinando o curso dos rios, o relevo, os acidentes geográficos, os rios que tinham águas calmas e navegáveis e ofereciam travessia, enfim, reunindo informações importantes da província que era completamente desconhecida das autoridades nacionais e provinciais. ${ }^{34}$

Além dessas atividades, os nativos exerceram, como registrado, uma importância fundamental no que tange ao abastecimento da Coluna expedicionária. Esta que marchava há meses e enfrentava inúmeras dificuldades de guarnecimento e provisões de gêneros 
alimentícios (carne, farinha, embutidos etc), teve que contar com a sabedoria milenar indígena:

\begin{abstract}
A área escolhida pelos indígenas para erigir o povoado de fugitivos era formada por uma densa floresta virgem, cujo solo era extremamente fértil. A princípio, tiveram os fugitivos que se contentar com uma dieta frugal de frutas nativas, palmitos, cocos da mata, mel de abelhas, caça e pesca. Os nativos, com grande conhecimento dos recursos da Serra de Maracaju, puderam disponibilizar os alimentos necessários para manter milhares de pessoas (NANTES, 1993). Logo. Derrubaram área expressiva e passaram a cultivar o solo, obtendo, em seguida, boas colheitas. ${ }^{35}$
\end{abstract}

Entretanto, as narrativas expressas pelos/as estudantes acerca da participação das distintas populações indígenas na Guerra do Paraguai/Guerra Guasu não fazem menção a esse rol de atividades que tais etnias protagonizaram no contexto do conflito. Tal fato, explica-se, ao menos, em parte, em função de que as narrativas didáticas de história ainda negligenciam ou pouco tangenciam o tema pertinente aos protagonistas subalternos, como é o caso das populações indígenas e seu protagonismo durante o conflito platino em defesa, inclusive, de seus interesses enquanto povos originários da referida Província.

Fonte C - Fotografia, de autoria e data desconhecidas, na qual estão retratados dois soldados brasileiros que lutaram na Guerra do Paraguai: um indígena Terena e outro Kadiwéu

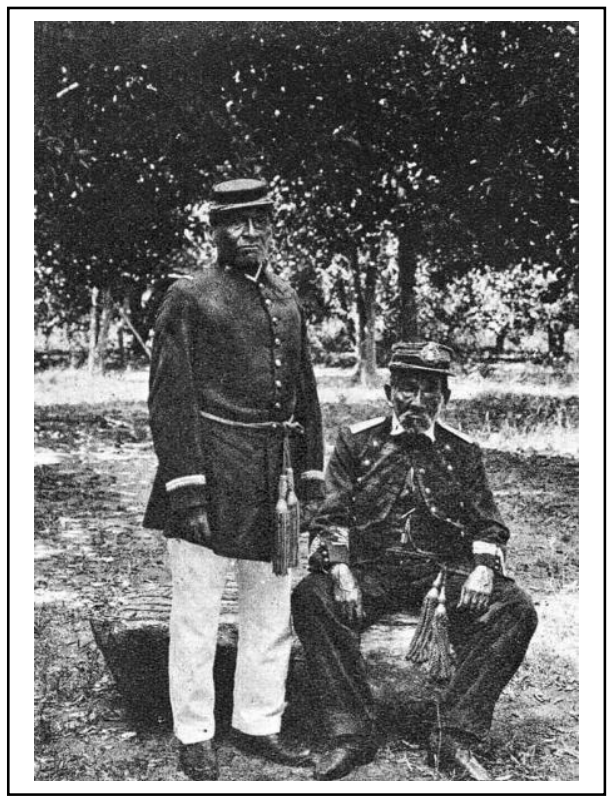

Fonte: Instrumento de Investigação. Projeto:

Narrativas da guerra: ideias de alunos e de manuais escolares de história no Brasil, Paraguai, Argentina e Uruguai - o que dizem sobre a Guerra Guasu?, 2017. 
As narrativas dos/das estudantes vão ao encontro de outra questão e se refere à relevante atuação desempenhada pelos povos nativos na defesa de suas terras:

\begin{abstract}
Quando da invasão paraguaia, alguns povos autóctones, principalmente os que se encontravam no sul de Mato Grosso, passaram a ter uma função importantíssima para a proteção e a garantia dos territórios do Brasil, ou melhor, para os territórios em que se encontravam suas aldeias. Os nativos não podiam desertar de suas regiões com a mesma facilidade dos europeus. ${ }^{36}$
\end{abstract}

Parte dos/das estudantes reconhecem que os indígenas integraram o exército imperial: “Os indígenas fizeram parte do exército brasileiro ${ }^{37}$ " e, corroboram as ideias relacionadas "à defesa", "à proteção" e, "à luta" por manter as terras nas quais as diferentes etnias indígenas habitavam; sendo assim, sobre a Fonte $\mathrm{C}$, registramos as narrativas históricas dos/as estudantes, as que se referem a ideia de "luta pela terra": "Esses homens são indígenas que lutaram para defender suas terras, porque os militares fugiram, então eles sobreviveram na guerra $^{38 " ; ~ " P o r q u e ~ o s ~ i n d i ́ g e n a s ~ f o r a m ~ o s ~ u ́ n i c o s ~ q u e ~ f i c a r a m ~ e ~ l u t a r a m ~ p o r ~ s u a s ~ t e r r a s ~ e ~ o s ~}$ paraguaios queriam tomar o Mato Grosso por conta que aqui tinha maior plantações e terras férteis",39. A ideia de "defesa da terra" também esteve presente: "Mostra que os indígenas se alistaram no exército para defender suas terras, porque os militares fugiram" ${ }^{\text {"40 }}$, assim como a de "salvar suas terras": "Eles ajudaram no combate da guerra para salvar suas terras". ${ }^{41}$

Por fim, um/uma dos/das estudantes sintetizou a triste realidade a que as populações indígenas ficaram submetidas após a Guerra, tendo seus sonhos e expectativas frustrados: "Os indígenas lutaram na Guerra do Paraguai em troca de reconhecimento das terras indígenas, muitos morreram, aldeias foram dizimadas e as terras não foram reconhecidas. Apenas muito tempo depois". 42

\title{
Considerações Finais
}

\section{A Guerra do Paraguai não foi totalmente do Paraguai...}

(GCD, 13 anos)

Pensar nas narrativas históricas de jovens estudantes concernentes a um conteúdo polêmico e instigante como é o da Guerra do Paraguai/Guerra Guasu constitui-se em um enorme desafio para o/a pesquisador/a da área. Como apontado no início dessa reflexão, estudos sobre as narrativas didáticas de história pertinentes a este assunto vêm se consolidando desde os anos 1980, o que não ocorre quando pensamos nas narrativas dos estudantes/as. 
Nesse sentido, o percurso dessa investigação levou-nos a algumas conclusões e/ou considerações mesmo que ainda parciais. Uma que apontamos é em relação ao formato do instrumento de investigação. Ao nosso ver e após a análise dos dados, averiguamos que ficou extenso, com muitas questões e talvez esse fato pode ter exaurido e desmotivado parte dos/das estudantes quando em contato com ele, pois, a maioria dos/as estudantes responderam à primeira parte do instrumento e alguns alunos/as não responderam a todas questões da segunda parte do instrumento. Para uma experiência futura, constatamos que o instrumento de investigação deve se constituir apenas da parte II.

No que se refere às narrativas didáticas analisadas, constatamos uma contradição em relação ao conteúdo sobre no Paraguai existir ou não a escravidão à época da Guerra. Estudos como os de Chiavenato aqui citado advogam que no Paraguai não havia escravidão, nesse sentido constitui-se uma contradição os negros escravizados integrarem o exército imperial e lutarem contra um país que não havia escravos. Entretanto, estudos recentes como os de Telesca (2010) comprovaram, a partir de fontes documentais, a existência da prática da escravidão no Paraguai ainda no contexto da Guerra. Em função de nas narrativas didáticas de história no Brasil ainda serem influenciadas pelas ideias gestadas por Chiavenato, alguns estudantes expressaram em suas narrativas essa questão em torno da incoerência dos negros escravizados lutarem pelo império contra um "país livre”.

As narrativas históricas dos/as jovens estudantes aqui analisadas permitiram que constatássemos também que os conteúdos relacionados à Guerra do Paraguai/Guerra Guasu ainda estão demasiadamente vinculados/associados/conectados com "as causas" da guerra: os motivos que levaram a Guerra, o desenrolar e as consequências; assim como tem-se uma ênfase nos grandes nomes envolvidos no conflito, como é o caso de Francisco Solano López e d. Pedro II. Nesse sentido, verificamos em tais narrativas uma "ausência da guerra vivida", uma ocultação/invisibilização da multiplicidade de sujeitos que configuraram a contenda, o espaço de protagonistas lhes é negado; justamente onde a historiografia avançou e os manuais didáticos de uma certa forma também, na medida que incorporaram novas fontes, como é o caso de charges, fotografias, pinturas, cinema, música, fragmentos de jornal etc e também novas abordagens sobre o tema.

Através da análise das narrativas históricas dos/das estudantes comprovamos também que os/as jovens possuem dificuldades em trabalhar com as fontes históricas, sejam elas textuais ou visuais. Não se trata de exigirmos do/da aluno/a uma postura de um "mini historiador/a", mas os/as alunos/as não encaram a fonte histórica com curiosidade e um 
campo de possibilidades. Isso se explica, ao menos em parte, porque, contrário a Portugal, por exemplo, onde a execução das aulas-oficinas levam à análise de distintas fontes e o próprio manual didático de história é permeado por fontes diferenciadas, no Brasil, ainda somos incipientes nessa prática didática; sendo que o texto principal (escrito) ainda possui, nas coleções didáticas de história, um destaque maior em relação a outras fontes, salvo algumas exceções, como a coleção didática História, Sociedade \& Cidadania de autoria de Alfredo Boulos Júnior.

Essa dificuldade refletiu em construções hilárias que expressam parte da cultura escolar em que os/as estudantes estão envolvidos/as; nas narrativas históricas algumas respostas aguçadoras foram registradas: "Não sei, pois não vim nesse dia"; "Informação indisponível”; "Eu não sei; desculpa"; "Eu estudei sobre Guerra do Paraguai, só que não lembro no momento"; "Não tenho que fazer isso, eu não sei... namoral [sic], Valeu!!!”; o uso corrente de gírias, expressões e vocabulários que conectam uma geração e, nesse caso, os/as estudantes usaram para justificar um conteúdo sobre a Guerra do Paraguai/Guerra Guasu (ou parte dele) que não dominavam. Os memes que marcam contemporaneamente as relações no mundo virtual também foram utilizados para argumentar sobre a ausência do conteúdo solicitado. 
Respostas à pergunta: 3.4 Imagine que você está na internet com pessoas de vários países e precisa contar-lhes a história da Guerra do Paraguai que envolve Brasil, Uruguai, Argentina e Uruguai. Faça um texto contando esta história.
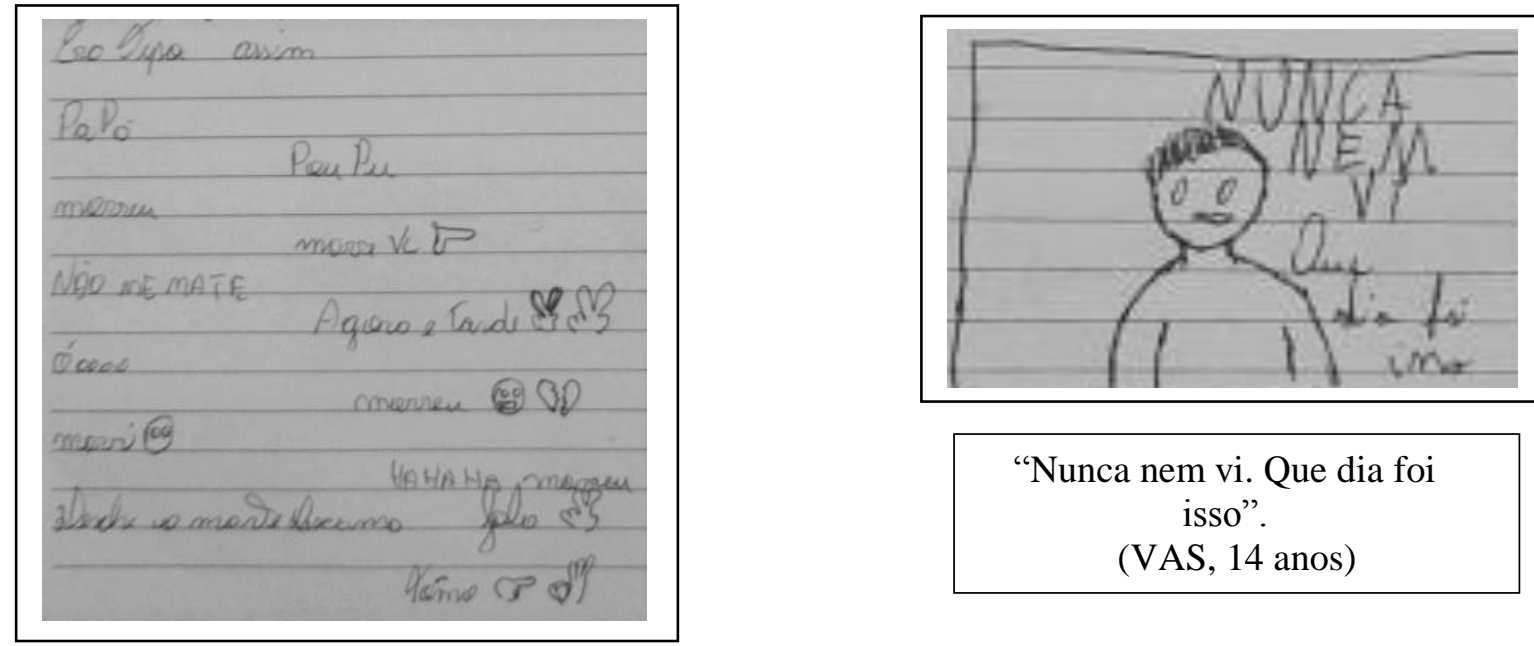

"Era tipo assim Pá Pá Pou Pu

Morreu Morre vc Não me mate

Agora é tarde Óoooo Morreu

Morri Hahaha morreu

Deiche (sic) a morte próxima Falo Tômo"

Fonte: Instrumento de Investigação. Projeto: Narrativas da guerra: ideias de alunos e de manuais escolares de história no Brasil, Paraguai, Argentina e Uruguai - o que dizem sobre a Guerra Guasu?, 2017.

Pensamos que algumas alternativas possam ser efetivadas para a mudança desse cenário. Um diálogo constante e contínuo entre estudiosos/as imbrincados na academia e professores/as que atuam na educação básica, desenvolvendo em conjunto cursos de formação, palestras, oficinas, ações que visem compreender os avanços historiográficas alçados no conteúdo sobre a Guerra do Paraguai/Guerra Guasu, podem vir a contribuir para a alteração desse cenário.

Essa alteração é necessária e deve promover no/na estudante o ato de empoderamento sobre a história, podendo, assim, orientá-lo para a vida prática e para o futuro, contribuindo ainda para que desenvolva posturas de alteridade e empatia, nesse caso, em especial, nas relações entre Brasil-Paraguai e que tenha um quadro pluriperspectivado sobre o tema.

Para encerrar, acreditamos que essa reflexão pode (e, deve) ter inúmeros desdobramentos: compreender as narrativas de professores/as, analisar documentos curriculares e ampliar a pesquisa para outros espaços como o Paraguai, Uruguai e Argentina 
são projetos que vislumbramos. Entretanto, a reflexão, a análise e os dados que ora apresentamos constituem-se em uma abordagem original e única (no espaço em que se insere) e trazem à tona elementos fundamentais para a compreensão sobre o conteúdo Guerra do Paraguai/Guerra Guasu.

\section{Notas}

${ }^{1}$ Tomamos como referência para a compreensão do conceito de historiografia didática os estudos desenvolvidos pela estudiosa Arlette Medeiros Gasparello, sobretudo a obra intitulada Construtores de Identidades: a pedagogia da nação nos livros didáticos da escola secundária brasileira. São Paulo: Iglu, 2004.

${ }^{2}$ POMBO, Rocha. História do Brasil. $9^{\mathrm{a}}$ ed. rev. e atual. Por Hélio Vianna. São Paulo: Edições Melhoramentos, 1960, p. 432.

${ }^{3}$ Idem, Ibidem, p. 432. (grifo nosso).

${ }^{4}$ POMBO, Rocha. Nossa Patria. Narração dos factos da historia do Brasil, através da sua evolução com muitas gravuras explicativas. 60 ed. Comp. São Paulo: Melhoramentos de São Paulo, 1917, p. 125.

5 BETHELL, Leslie. A Guerra do Paraguai: história e historiografia. In: MARQUES, Maria Eduarda Castro Magalhães (org.). A Guerra do Paraguai: 130 anos depois. 2a ed. rev. Rio de Janeiro, Relume-Dumará, 1995, p. 22.

${ }^{6}$ Cf.: Instrumento de Investigação respondido por PHSM, 13 anos.

${ }^{7}$ Cf.: Instrumento de Investigação respondido por AAS, 13 anos.

${ }^{8} \mathrm{Cf}$.: Instrumento de Investigação respondido por JR, 13 anos.

${ }^{9}$ Cf.: Instrumento de Investigação respondido por GDO, 13 anos.

${ }^{10} \mathrm{Cf}$.: Instrumento de Investigação respondido por EF, 13 anos. (grifo nosso).

${ }^{11} \mathrm{Cf}$.: Instrumento de Investigação respondido por AF, 15 anos. (grifo nosso)

${ }^{12} \mathrm{Cf}$.: Instrumento de Investigação respondido por JIDS, 14 anos.

${ }^{13} \mathrm{Cf}$.: Instrumento de Investigação respondido por JIDS, 14 anos.

${ }^{14} \mathrm{Cf}$.: Instrumento de Investigação respondido por PBA, 14 anos.

${ }^{15}$ Cf.: Instrumento de Investigação respondido por RWMDS, 14 anos. (grifo nosso)

${ }^{16}$ BARRETO VALINOTTI, Ana. Las mujeres. Asunción: El Lector, 2013. (Colección 150 años de la Guerra Grande), p. 21.

${ }^{17}$ Idem, Ibidem, p. 29.

${ }^{18}$ Idem, Ibidem, p. 52.

${ }^{19}$ Cf.: Instrumento de Investigação respondido por ECCDODS, 15 anos.

${ }^{20} \mathrm{Cf}$.: Instrumento de Investigação respondido por JDSS, 15 anos.

${ }^{21} \mathrm{Cf}$.: Instrumento de Investigação respondido por JIDS, 14 anos.

${ }^{22}$ Cf.: Instrumento de Investigação respondido por ADPDS, 14 anos.

${ }^{23}$ SALLES, Ricardo. Guerra do Paraguai: escravidão e cidadania na formação do Exército. Rio de Janeiro: Paz e Terra, 1990, p. 61.

${ }^{24}$ TORAL, André Amaral de. A participação dos negros escravos na Guerra do Paraguai. Estudos Avançados USP, vol. 9, $\mathrm{n}^{\mathrm{o}}$. 24, agosto de 1995. p. 287-296. Disponível em: http://www.revistas.usp.br/eav/article/view/8880/10432. Acessado em: 04 de novembro de 2019, p. 287.

${ }^{25}$ SALLES, Ricardo. Op. Cit., p. 70.

${ }^{26}$ TORAL, André Amaral de. Op. Cit., p. 292.

27 TORAL, André Amaral de. Op. Cit., p. 292.

${ }^{28}$ Cf.: Instrumento de Investigação respondido por CEDSS, 13 anos.

${ }^{29} \mathrm{Cf}$.: Instrumento de Investigação respondido por FPDA, 13 anos.

${ }^{30}$ Cf.: Instrumento de Investigação respondido por GCFDS, 13 anos.

${ }^{31}$ SALLES, Ricardo. Op. Cit., p. 73.

${ }^{32}$ SALLES, Ricardo. Op. Cit., p. 65.

${ }^{33}$ ESSELIN, Paulo Marcos; VARGAS, Vera Lúcia Ferreira. A participação dos indígenas de banda meridional da capitania de Mato Grosso na Guerra do Paraguai. História: debates e tendências, vol. 15, nº 2, jul/dez 2015, p. 377. 
${ }^{34}$ Idem, Ibidem, p. 377.

${ }^{35}$ Idem, Ibidem, p. 375.

${ }^{36}$ Idem, Ibidem, p. 373.

${ }^{37} \mathrm{Cf}$.: Instrumento de Investigação respondido por NDOF, 13 anos.

38 Cf.: Instrumento de Investigação respondido por ELDS, 14 anos.

39 Cf.: Instrumento de Investigação respondido por ABF, 16 anos.

${ }^{40} \mathrm{Cf}$.: Instrumento de Investigação respondido por RDNV, 14 anos.

${ }^{41} \mathrm{Cf}$.: Instrumento de Investigação respondido por CW, 14 anos.

${ }^{42} \mathrm{Cf}$.: Instrumento de Investigação respondido por RFDO, 14 anos.

\section{Referências}

ALENCAR, Francisco; RAMALHO, Lúcia Carpi; RIBEIRO, Marcus Venicio. História da sociedade brasileira. Rio de Janeiro: Ao Livro Técnico, 1994.

ARAÚJO, Tiago Gomes de. O ensino de um conflito: a Guerra do Paraguai (186401870) nos Livros Didáticos brasileiros (PNLD-EM 2012-2014). In: SQUINELO, Ana Paula (org.). 150 anos após - a Guerra do Paraguai: entreolhares do Brasil, Paraguai, Argentina e Uruguai. Campo Grande: Ed. UFMS, 2016, pp. 135-167. (volume 2)

BANDEIRA, Moniz. O expansionismo brasileiro e a formação dos Estados na Bacia do Prata: da colonização à Guerra da Tríplice Aliança. 2. ed. São Paulo: Ensaio; Brasília: UNB, 1995.

BARCA, Isabel. Educação Histórica: uma nova área de investigação. Revista da faculdade de Letras, Porto, III Série, vol. 2, 2001, p. 013-021.

BARCA, Isabel. Aula Oficina: do projecto à avaliação. In: BARCA, Isabel (org.). Para uma Educação Histórica de qualidade. Actas das quartas Jornadas Internacionais de Educação Histórica. Portugal: Universidade do Minho; CIEd, 2004, pp. 131-144.

BARRETO VALINOTTI, Ana. Las mujeres. Asunción: El Lector, 2013. (Colección 150 años de la Guerra Grande)

BARRETO VALINOTTI, Ana. Silvia Cordal. La niña que vivió para contarlo. Asunción: Grupo Editorial Atlas, 2020. (Protagonitas de la Guerra Guasu)

BETHELL, Leslie. A Guerra do Paraguai: história e historiografia. In: MARQUES, Maria Eduarda Castro Magalhães (org.). A Guerra do Paraguai: 130 anos depois. $2^{\mathrm{a}}$ ed. rev. Rio de Janeiro, Relume-Dumará, 1995.

BORGES, Fernando Tadeu de Miranda; PERARO, Maria Adenir (orgs.). Brasil e Paraguai: uma releitura da guerra. Cuiabá/MT: Entrelinhas; EdUFMT, 2012.

BORRIES, Bodo von. Lidando com histórias difíceis: tipos de reconciliação com danos e culpas históricas. In: SCHMIDT, Maria Auxiliadora; FRONZA, Marcelo; NECHI, Lucas Pydd (orgs). Jovens e consciência histórica. Bodo von Borries. Curitiba: W.A. Editores, 2018, p. 33-54. 
BOULOS Júnior, Alfredo. História: sociedade \& cidadania. 2. ed. ref. São Paulo: FTD, 2012.

CAPDEVILA, Luc. Uma guerra total: Paraguay, 1864-1870: ensayo de historia del tempo presente. 1. ed. Buenos Aires: SB, 2010.

CARVALHO, José Murilo. Jovita Alves Feitosa: voluntária da pátria, voluntária da morte. São Paulo: Chão Editora, 2019.

CHIAVENATO, Júlio José. Genocídio americano: A Guerra do Paraguai. $1^{\text {a }}$ ed. São Paulo, Moderna, 1998. (Coleção Polêmica)

CERQUEIRA, Dionísio Evangelista de Castro. Reminiscências da Campanha do Paraguai, 1865-1870. Rio de Janeiro: Biblioteca do Exército, [s.d.].

COSTA, Wilma Peres. A espada de Dâmocles: o exército, a guerra do Paraguai e a crise do império. São Paulo: Editora Hucitec; Editora da UNICAMP, 1996.

DOCKHORN, Vera Lúcia Nowotny. O ensino da Guerra do Paraguai através das imagens: uma proposta para o uso da fotografia e da pintura como fonte de ensino. 2020. Dissertação (Mestrado Profissional em Ensino de História) - Programa de Mestrado Profissional em Ensino de História (PROFHISTÓRIA), Universidade Federal de Mato Grosso, Cuiabá, 2020.

DOCKHORN, Vera Lúcia Nowotny. A Guerra do Paraguai: historiografia e imagens nas coleções didáticas História Global, História Sociedade \& Cidadania e História (PNLD 2018). In: SQUINELO, Ana Paula (org). Livro Didático e Paradidático de História em tempos de crise e enfrentamento: Sujeitos, Imagens e Leituras. Campo Grande-MS: Ed. Life, 2020, pp. 441-70.

DORATIOTO, Francisco. Maldita Guerra: Nova história da Guerra do Paraguai. $2^{\mathrm{a}}$ ed. São Paulo, Companhia das Letras, 2002.

DOURADO, Maria Teresa Garritano. Mulheres comuns, senhoras respeitáveis: a presença feminina na Guerra do Paraguai. Campo Grande, MS: Ed. UFMS, 2005.

DOURADO, Maria Teresa Garritano. A história esquecida da Guerra do Paraguai: fome, doenças e penalidades. Campo Grande, MS: Ed. UFMS, 2014.

DOURADO, Maria Teresa Garritano. Viúvas e descendentes dos combatentes da Guerra do Paraguai. In: SQUINELO, Ana Paula (org.). 150 anos após - a Guerra do Paraguai: entreolhares do Brasil, Paraguai, Argentina e Uruguai. Campo Grande: Ed. UFMS, 2016, pp. 303-316. (volume 1)

ESSELIN, Paulo Marcos; VARGAS, Vera Lúcia Ferreira. A participação dos indígenas de banda meridional da capitania de Mato Grosso na Guerra do Paraguai. História: debates e tendências, vol. 15, nº 2, jul/dez 2015, p. 367-382. 
FIGUEIRA, Divalte Garcia. Soldados e negociantes na Guerra do Paraguai. São Paulo: Humanitas FFLCH-USP: FAPESP, 2001.

GARCIA, Gabriel Ignacio; ARIAS NETO, José Miguel. A imprensa como soldado da Tríplice Aliança e do Paraguai: guerra total e desumanização do inimigo. In: SQUINELO, Ana Paula (org.). 150 anos após - a Guerra do Paraguai: entreolhares do Brasil, Paraguai, Argentina e Uruguai. Campo Grande: Ed. UFMS, 2016, pp. 251-273. (volume 1)

GASPARELLO, Arlette Medeiros. Construtores de Identidades: a pedagogia da nação nos livros didáticos da escola secundária brasileira. São Paulo: Iglu, 2004.

IZECKSOHN, Vitor. A Guerra do Paraguai. In: GRINBERG, Keila; SALLES, Ricardo (org.). O Brasil imperial: 1831-1870. 2. ed. Rio de Janeiro: Civilização Brasileira, 2011.

KMIECIK, Daniele Sikora. Aprendizagem histórica: as narrativas históricas de jovens estudantes sobre a Guerra do Paraguai. In: Os desafios da escola pública paranaense na perspectiva de professores PDE - Produções Didáticos Pedagógicas. Governo do Estado do Paraná/Secretaria de Educação: Paraná, 2016. (volume II).

MACEDO, Joaquim Manoel de. Lições de historia do Brazil, para uzo dos alumnos do Imperial Collegio de Pedro Segundo. Rio de Janeiro: Tipografia Imparcial de J.M.N. Garcia, 1861.

MARIN, Jérri Roberto; SQUINELO, Ana Paula. A ocupação paraguaia em Mato Grosso 1'1durante a Guerra do Paraguai. Revista Territórios \& Fronteiras, Cuiabá-MT, volume 12, n.2, ago. - dez. 2019, p. 76-103.

MARQUES, Adhemar Martins; BERRUTTI, Flávio; FARIA, Ricardo. História: os caminhos do homem. Belo Horizonte: Ed. Lê, 1995.

MARQUES, Maria Eduarda Castro Magalhães (org.). Guerra do Paraguai: 130 anos depois. Rio de Janeiro: Relume - Dumará, 1995.

MOREIRA, Valéria Cristina. Ensino de História e RPG como ferramenta nos estudos regionais: possibilidades em "A Retirada da Laguna" de Alfredo d'Escragnolle Taunay. 2018. Dissertação (Mestrado Profissional em Ensino de História) - Programa de Mestrado Profissional em Ensino de História (PROFHISTÓRIA), Universidade Estadual de Mato Grosso do Sul, Unidade Universitária de Amambai, 2018.

OLIVEIRA, Jorge Eremites de; PEREIRA, Levi Marques. "Duas no pé e uma na bunda": da participação terena na Guerra entre o Paraguai e a Tríplice Aliança à luta pela ampliação dos limites da Terra Indígena Buriti. Revista Eletrônica História em Reflexão, vol. 1, n 2, UFGD, Dourados, jul - dez, 2007.

POMBO, Rocha. Nossa Patria. Narração dos factos da historia do Brasil, através da sua evolução com muitas gravuras explicativas. $60^{a}$ ed. Comp. São Paulo: Melhoramentos de São Paulo, 1917. 
POMBO, Rocha. Compendio de Historia da America. $2^{\mathrm{a}}$ ed. Rio de Janeiro: Benjamin de Aguila, Editor, 1925.

POMBO, Rocha. História do Brasil. 9a ed. rev. e atual. Por Hélio Vianna. São Paulo: Edições Melhoramentos, 1960.

POMER, León. La Guerra del Paraguay; Gran Negocio! Buenos Aires, Caldén, 1968.

POTTHAST, Jutkelt Bárbara. "Paraíso de Mahoma” o "El País de las Mujeres”? Asunción: Litocolor SRL, 1996.

RIBEIRO, Marcus Venicio; ALENCAR, Chico; CECCON, Claudius. Brasil Vivo: uma nova história da nossa gente. Petrópolis: Vozes, 1988.

RODRIGUES, Fernando da Silva; PEDROSA, Fernando Velôzo Gomes (orgs.). Uma tragédia americana: a Guerra do Paraguai sob novos olhares. Curitiba: Ed. Prismas, 2015.

RODRÍGUEZ ALCALÁ, Guido. Residentas, Destinadas y Traidoras. Testimonio de Mujeres de la Triple Alianza. Asunciónn: Servilibro, Cuarta Edición, 2010.

SALLES, Ricardo. Guerra do Paraguai: escravidão e cidadania na formação do Exército. Rio de Janeiro: Paz e Terra, 1990.

SALLES, Ricardo. Guerra do Paraguai: Memórias \& Imagens. Rio de Janeiro: Edições Biblioteca Nacional, 2003.

SALLES, André Mendes; BATISTA NETO, José. A Guerra do Paraguai como conhecimento escolar: as razões para o conflito em Livros Didáticos de História do Brasil (1886-1999). In: SQUINELO, Ana Paula (org.). 150 anos após - a Guerra do Paraguai: entreolhares do Brasil, Paraguai, Argentina e Uruguai. Campo Grande: Ed. UFMS, 2016, p. 77-105. (volume 2)

SALLES, André Mendes. Livro Didático, prática pedagógica e professor de história. In: SQUINELO, Ana Paula (org). Livro Didático e Paradidático de História em tempos de crise e enfrentamento: Sujeitos, Imagens e Leituras. Campo Grande-MS: Ed. Life, 2020, p. 87-115.

SANSÓN CORBO, Tomás. Identidad y alteridade en los manuales de historia rio-platenses. Las representaciones de Paraguay. Diálogos, v. 15, n. 1, p. 41-63, 2011.

SCHWARCZ, Lilian Moritz et al. A Batalha do Avaí: a beleza da barbárie: a Guerra do Paraguai pintada por Pedro Américo. Rio de Janeiro: Sextante, 2013.

SILVA, Giovani José da Silva. Protagonistas indígenas em Mato Grosso (do Sul): memórias, narrativas e ritual Kadiwéu sobre a Guerra (sem fim) do Paraguai. Revista Brasileira de História \& Ciências Sociais - RBHCS, vol. 10, nº 20, jul - dez, 2018.

SILVEIRA, Mauro César. A batalha de papel: A Guerra do Paraguai através da caricatura. Rio Grande do Sul: L\&PM, 1996. 
SOUSA, Jorge Prata de. Escravidão ou Morte: os escravos brasileiros na Guerra do Paraguai. Rio de Janeiro: Mauad:ADESA, 1996.

SQUINELO, Ana Paula. A Guerra do Paraguai, essa desconhecida... Ensino, memória e história de um conflito secular. 1. ed. Campo Grande-MS: 2002.

SQUINELO, Ana Paula. A Guerra do Paraguai ontem e hoje: Mato Grosso e Mato Grosso do Sul (1868-2003). Campo Grande, MS, Ed. UFMS, 2015.

SQUINELO, Ana Paula (org.). 150 anos após - a Guerra do Paraguai: entreolhares do Brasil, Paraguai, Argentina e Uruguai. Campo Grande: Ed. UFMS, 2016. (volumes 1 e 2)

SQUINELO, Ana Paula. "O imperialismo inglês não quer mudanças no mundo": a Guerra do Paraguai na literatura escolar brasileira (1987-2001). In: SQUINELO, Ana Paula. (org.). 150 anos após - a Guerra do Paraguai: entreolhares do Brasil, Paraguai, Argentina e Uruguai. Campo Grande: Ed. UFMS, 2016, p. 47-75. (volume 2)

SQUINELO, Ana Paula. História \& Literatura, Cotidiano \& Sertão - perspectivas de gênero na obra Cunhataí: um romance sobre a Guerra do Paraguai (Brasil, 2003). In: FRASQUET, Ivana; ESCRIG, Josef; RENAU, Laura Martínez (eds). Anais XII Congresso AHILA. En los margénes de la historia tradicional. Nuevas miradas de America Latina desde el siglo XXI. Espanha: Universitat de Valencia, 2017, pp. 236-60.

SQUINELO, Ana Paula. O Oficial, o Chamigo e a Fera: a Guerra do Paraguai nos Livros Paradidáticos brasileiros. In: SQUINELO, Ana Paula; TELESCA, Ignacio (orgs.). 150 anos após - a Guerra do Paraguai: entreolhares do Brasil, Paraguai, Argentina e Uruguai. Campo Grande: Ed. UFMS, 2019, p. 345-379. (volume 3).

SQUINELO, Ana Paula. Mulheres na Guerra do Paraguai: uma proposta de Aula-Oficina a partir da história em quadrinhos: "Adeus, Chamigo brasileiro". In: SQUINELO, Ana Paula (org.). Livro Didático e Paradidático de História em tempos de crise e enfrentamento: Sujeitos, Imagens e Leituras. Campo Grande-MS: Ed. Life, 2020, p. 57-86.

SQUINELO, Ana Paula; TELESCA, Ignacio (org.). 150 anos após - a Guerra do Paraguai: entreolhares do Brasil, Paraguai, Argentina e Uruguai. Campo Grande: Ed. Life, 2019. (volume 3)

TAUNAY, Alfredo d'Escragnolle. A Retirada da Laguna: episódio da Guerra do Paraguai. Tradução e Organização de Sérgio Medeiros. São Paulo: Companhia das Letras, 1997. (Retratos do Brasil).

TELESCA, Ignacio (coord.). Historia del Paraguay. Paraguay: Taurus, 2010.

TELESCA, Ignacio. Paraguay em el Centenario: la creación de la nación mestiza. $H$ Mex, LX:1, 2010, p. 137-195. 
TELESCA, Ignacio. La guerra em la escuela. Textos de lectura y celebraciones escolares em el Paraguay em fins del XIX y inicios del XX. Folia Historica del Nordeste, $\mathrm{n}^{\mathrm{o}} 24$, Resistência, Chaco, Deciembre, 2015, p. 131-50.

TERAN, Leopoldo; GAMBA, Próspero. Compendio de Historia del Paraguay. 16 ${ }^{\mathrm{a}}$ ed. Asunción: Tipografia Quell \& Cia, 1920.

TORAL, André Amaral de. A participação dos negros escravos na Guerra do Paraguai. Estudos Avançados - USP, vol. 9, no. 24, agosto de 1995. p. 287-296. Disponível em: http://www.revistas.usp.br/eav/article/view/8880/10432. Acessado em: 04 de novembro de 2019.

TORAL, André. Adeus, Chamigo brasileiro - uma história da guerra do Paraguai. São Paulo: Companhia das Letras, 1999.

TORAL, André. Imagens em desordem. A iconografia da Guerra do Paraguai (1864-1870). São Paulo: Humanitas/FFLCH/USP, 2001.

VELÁZQUEZ SEIFERHELD, David Rafael. "Hacer aprender a los ñinos de memoria todos los artículos concernientes a ellos..." Um reglamento de escuela de primeiras letras de tiempos de Francisco Solano López (Paraguay, 1864). In: SQUINELO, Ana Paula; TELESCA, Ignacio (org.). 150 anos após - a Guerra do Paraguai: entreolhares do Brasil, Paraguai, Argentina e Uruguai. Campo Grande: Ed. Life, 2019, p. 435-58. (volume 3)

VELÁZQUEZ SEIFERHELD, David Rafael. Los libros escolares en el Paraguay hasta 1955. La nación, 22 de jun de 2020. Disponível em https://www.lanacion.com.py/gran-diariodomingo/2020/06/21/los-libros-escolares-en-el-paraguay-hasta-1955/, acesso em 13 de agosto de 2020 . 